\title{
From Drugs to Peace? Resetting the Conversation
}

Jenny Pearce

Introduction

It has never been easy to have an evidence based conversation about drugs cultivation, processing, trafficking and/or consumption. The 'war on drugs' created a militarised narrative around narcotics. And as this Special Issue demonstrates, when combined with a narco frontier imaginary' (Goodhand, this volume), in which borderland drugs producing regions of the Global South are constructed as hearts of darkness, the impossibility of a serious conversation has grown. If 'prohibition' followed by the 'war on drugs' dominated the discussion in the twentieth century, it is fumigation and 'alternative development' which began the 21 st, providing new tactics of the war. This has continued to be waged on the supply of drugs. The relationship of drugs to funding armed groups connected them to security fears and from there to the field of peace building as well as development as part of a new arsenal for addressing these insecurities. However, the benign narratives connecting drugs, development and peace (the 'trilemma' as the introductory essay calls it) contrasts greatly with the effectiveness and social impacts of these policy frameworks in practice. Approaches to drugs which promote inclusive well being and reduce violence remain elusive.This Special Issue is attempting, therefore, to reset the conversation again and dig more deeply into the logics behind the 'trilemma' and the assumed convergence of drugs, 
development and peace building behind it. It takes a very particular starting point: that of impoverished, coca and opium growing/processing and transporting frontier regions, which have experienced armed conflict and/or its aftermath. It encourages us not to parachute into these 'problem zones' with our worries about the ongoing supply of illegal drugs, imagining a straightforward universal remedy of crop substitution and 'alternative development' leading to peace and prosperity. Rather, these frontier zones should be viewed as dynamic social spaces with specific topographies, histories and cultures, enmeshed in complex geopolitical environments. If drugs policy is to adequately engage with the mutating dynamics around drugs in these specific contexts, it needs to start from their temporal and spatial specificities and to understand the logics of the choices facing populations who live there.

There is no straightforward road from drugs to peace. And navigation is infinitely complicated and limited by the framework above. This Viewpoint reflects on how the Special Issue contributes to new approaches to navigating this road by re-evaluating our knowledge and understanding of the borderlands where the road often starts and where drugs cultivation, processing and transport are concentrated, giving varied roles and opportunities to local and external actors. It highlights three ways to reboot the conversation around the drugs problem and enable a new mapping of the road ahead: drugs as an inequality issue; drugs, perverse state formation and violence; and drugs and social agency. These are not the only issues that matter, of course. The drugs business is a complex accumulation enterprise, where each 'end' of the road, producers (cultivators and processors) and consumers, are vital to each other, alongside the use by varied illegal and legal actors of the capital accumulated (from money laundering to political bribes) and the effects this has along the road and the byways which constitute the transport corridors and local sales. However, the benefit of this Special Issue is that it enables us to focus more specifically on key areas 
where drugs are a major component of local economies and ecologies. Rather than pathologise such contexts, it encourages us to see the entire road as an interconnected highway embedded in wider and global systems of inequality and where policy remains trapped in a securitising and developmentalist mindset.

\section{Drugs within Systems of Inequality}

This Special Issue has consciously focused on the lowest end of the value chain of the drugs business: peripheral frontier areas. However, it highlights the inequalities within that value chain, and at every stage of its realisation, as well as the potential distributive impacts (or not) of global drugs policy. If drugs cultivation is rooted in a wider system of inequalities, how can drugs policy seriously address the problem of drugs without addressing that system?

The drugs business has flourished within systems of inequalities, which only begin with drugs cultivation, and then pass through the processing, transport and trafficking, money laundering and consumption. North-South inequalities are integral to this system, and hence the developmentalist turn of the drugs debate. This is highly contingent upon priorities set by the Global North, including those ecological and health ones, that have resulted in readiness to use the chemical glyphosate with its proven harms, to eradicate the coca plant (Rhodes, et al, this volume). However, this division is also apparent in the consumption and health disorder patterns around drugs at the other end of the road. Although this Special Issue is about populations in drugs producing areas, (where local consumption and transporting also take place), it is worth simply noting the latest (2020) UNODC report. This shows that around 269 million people used drugs in 2018, an increase of 30 per cent 
from 2009. Of these, 35.6 million suffer from drug use disorders globally:' While more people use drugs in developed countries than in developing countries, and wealthier segments of society have a higher prevalence of drug use, people who are socially and economically disadvantaged are more likely to develop drug use disorders'(UNODC:2020a:1). Thus the report argues:

'Within individual countries, the degree of income inequality is related to the prevalence of drug use such that the countries with the highest levels of socioeconomic inequality tend to have the highest prevalence of drug use disorders. Insufficient investment in public policies and high levels of stress among individuals accompany such income disparities. In addition, dramatic changes in macroeconomic conditions, such as those arising from a political or economic crisis, result in increases in poverty and unemployment which in turn influence individuals' socioeconomic prospects and stress levels, and may also lead to increases in rates of drug use' (UNODC, 2020b:12)

There is no space to discuss the details of the inequalities that pave the routes from cultivation to consumption. However, drugs trafficking is also inserted into vastly differentiated opportunities open to young men, in particular, in the highly gendered stratifications of producing countries and in the distribution networks in both the global South and the global North. The foot soldiers of these processes will be mostly drawn into their occupation through the lack of other options for an income, identity, belonging and status. In Latin America, there is a 1 in 50 chance of dying before you reach the age of 31 if you are a poor young man living in a low income setting (Moetue et al. 2013).

Inequalities therefore, play out in varied domains: in social relationships (class, gender, ethnicity, belief systems, generation) but also rural/urban, centre/periphery divides, and in 
the political economy of power highlighted by the introductory essay to this volume. In addition, they are outcomes of the economic thinking and policy practices which have privileged certain forms of accumulation over others, and protected them politically, despite evidence that they generate further inequalities. Thus Meehan (this issue) points out in the case of Myanmar, that those who cultivate drugs are not just 'left behind' by development but are actually victims of the assumptions about what 'development' is. Market-led rural development has actually pushed the rural poor into opium cultivation. The interventions of Pakistan on its western border with Nangarhar in Afghanistan in 2015 and Iran on its eastern border with Nimroz in Afghanistan (Koehler, this volume), both impacted hugely on the cross border economies and the livelihoods of those dependent on cross border flows of licit and illicit commodities. The volatile political economy of these regions is easily unsettled by policies to make the presence of the State felt but which take no account of the informal borderland economies on which many survive. Nevertheless, making the State's presence felt is understood to be part of the developmentalist agenda. The existing patterns of advantage and disadvantage are largely ignored in these developmental interventions.

In Colombia, the case I know best, inequality is at the heart of centre-periphery relations within which coca growing areas are located, as well as the rural-urban inequalities which have marked Colombia over the last decades. The country's urban population doubled between the census years of 1964 and 1985 (Pearce, 1990:69) reaching 81 percent of the population according to the World Bank in 2019. The shift in the 1950s and 1960s was originally due to forced displacement through the vicious mid-century inter party conflict known as 'The Violence'. While many headed for cities, others colonised the agricultural frontier in search of land and safety. This was followed in many rural areas by displacement due to agricultural modernisation and development itself. Struggles over a landowner 
or peasant path (LeGrand, 1986) to development have overshadowed Colombia, with the former resisting the latter- often with violence but also through political leverage. In the meantime, peasant colonisers struggled to build livelihoods in inhospitable and unregulated environments, in which historian of the colono, Alfredo Molano, concluded 'coca prevented the decomposition of the peasant economy' (Molano, 1989). Today Colombia has one of the most unequal distributions of land in the world, as well as what authors of a 2015 mission into the transformation of the countryside call a 'heterogenous rural geography'. Regional inequalities mean that some rural areas are strongly articulated with large and intermediary cities, while others, extremely poor areas, are in the most distanced regions of the country (Misión Para la Transformación del Campo, 2015:11). In this context, Sanin (this volume) explains how coca growing is not only a vital livelihood, but for some, offers a minimum pathway to a 'step on the ladder' for the children of coca farmers, through funding education, for instance. Coca in that sense is development within the prevailing system of inequalities. The problem is that while coca and opium may in some circumstances offer a developmental path from the perspective of the disadvantaged, it does so without the regulation of a third party, ie the rule of law.

\section{Drugs, Perverse State Formation and Violences}

Drugs policy often invokes a Weberian imaginary of a state that legitimately monopolises violence over a given territory, juxtaposed to the absence, failure and fragility of those states that have 'enabled' illicit cultivation. As the authors of the introductory essay point out, borderlands are sites which expose the ongoing struggles over territory and sovereignty in many parts of the world. The authors (this volume) speak of 'borderland blindness 
' and 'state-centric biases'. Rather than set reality against a 'normal' Weberian state, however, it is arguably more appropriate to inductively learn about the meaning of statehood and its functions in these areas and other regions. Not only can the Weberian imaginary of the State be challenged on its own terms (Pearce, 2020), but the state formation processes in much of the global South are on a trajectory of their own, not a deviated one from an imagined Weberian 'norm'. This 'perverse' state formation (Pearce, 2010) is not an 'anormal' to the 'normality' of the Weberian path, it is a process of state formation in its own right and on its own terms. Unlike the Weberian ideal, which remains so potent as an imaginary, it disperses the use of violence and fails to build legitimacy through safe and uncorrupted democratic participation and an equitable and accessible rule of law.

Francisco Thoumi puts this point well in relationship to Latin America: 'The challenge that organised crime presents for the state is how to impose the rule of law. One option is to co-opt and control criminal organisations, allowing them to operate within some "reasonable" limits. This might have worked in the past, but it is unlikely to work now. The other option is to impose the rule of law, not just by a strong arm of the state but by having it internalised by the citizenry, by making them full modern citizens with a sense of belonging to the state so that the socially accepted norms coincide with the formal legal requirements. This is, of course, a huge challenge. The question is whether countries like Colombia and Mexico are ready to respond to it' (Thoumi, 2019)

In Colombia, the borderlands express varied battles between the interests of the State, paramilitary, organised crime and insurgent groups, with deep historical roots and in which the economic implosion of Venezuela has generated major new instabilities along its borders with Colombia. Dynamic interactions between states and their peripheries, and between varied armed actors highlight the impacts of violence reproducing, state formation in Latin America. 
The corollary of this is that the use of violence remains dispersed, and becomes more organised and collective when conditions allow it and incentives promote it. This is not as anarchic as it appears. In the case of Urabá in Colombia, another borderland region,

Ballvé (2020) has made a powerful case for paramilitary actors and drug traffickers seeing themselves as 'state builders', who ensured roads were built while they also dispossessed peasants and then manipulated land titles to enable private business to build an African Palm Oil economy in the 2000s. Others have discussed the orders constructed by the FARC guerrillas in coca growing borderlands, and also attributed road building to them as well as forms of de facto justice. Certainly, armed actors might 'order' the violences on these peripheries. This form of 'micro-monopolisation' however, might generate acceptance for want of alternatives, but this is not equivalent to freely granted consent that builds legitimate authority. Rather, this reflects the wider disregard of multiple violences impacting on communities in the country as a whole. Of these, war violences are only one. Non war violences far exceed violences related to armed conflict and peace accords do not appear to necessarily diminish these (Pearce and Perea, 2019). The big challenge is to begin the debate on what a violence reducing state might look like. Sanin (this volume) found that coca growers would give up coca growing in certain circumstances, and one of these includes the provision of a secure environment alongside opportunities for a dignified livelihood. How then to begin the debate on the ground in these frontier zones?

\section{Drugs Cultivation and Borderlanders' Social Agency}

A particularly strong thread in this Special Issue is the way it dialogues with community actors through the research. In that sense it recognises that there is agency on the ground, agency that could be enlisted in the search for policies towards drugs that take account of 
lived realities and how they are navigated. There are varied kinds of agency. Several articles focus on the collective action of the Pat Jasan Drug Eradication social movement in Northern Myanmar, to draw attention to the experiential knowledge which drives their social action compared with the 'expert' and external knowledge which influences policy but lacks that meaningful everyday knowledge. The importance of listening to borderland voices and acknowledging the difficult choices they are faced with, is emphasised by other studies. Idler in her study of violence, crime and governance at the edges of Colombia's war, noted how 'borderlanders affirm their independence from the state through their agency', transgressing the border between states, the legal and the illegal and a national citizenry and a cross-border community, thus 'calling into question the concept of citizens security and, as such, an unequal practice of democratic governance' (Idler: 2019:295). By treating citizens on the ground as not only already acting within the multiple social, economic and political constraints they face, but also capable of engaging in more productive, violence reducing and law constituting processes, drug reform policy could begin to dig deeper roots, capable of sustaining the goals of eradication and violence reduction. And, an ecological lens (Rhodes, et al, this volume), takes on board the agency of non human actors, and how the drug war in Colombia generated an ecological war between the chemical glyphosate and the coca plant, with devastating impacts on the local environment and the health of its population.

\section{Conclusion}

Digging deeper roots with communities in drug cultivating borderlands will not be a 'quick fix'. However, it is evident that there is no rapid solution to the drugs problem. Drug cultiva- 
tion and processing mutates as do the ways actors in all parts of the production and trafficking chains adapt to new pressures and opportunities. This is exemplified by evidence of shifts in the efficiency of cocaine manufacture in Colombia, for example. The concentration of coca leaf production in high-yield areas and on larger plots and improvements in agricultural practices and the age structure of the coca bush plants, have led to higher yields of coca leaf, from an average of 4.7 tons of fresh coca leaf per hectare in 2014 to 5.7 tons per hectare in 2018 (UNODC, 2020c: 22). The same report noted changes in cocaine manufacturing. As coca grower protection by the FARC ended with the peace process and the FARC vacated traditional territories, farmers became more involved in the processes requisite to the manufacture of cocaine (ibid.). Insight Crime (2020) reported that organized crime groups have increasingly been able to obtain more cocaine from fewer crops.

This constant adaptation poses new dilemmas for policy makers. This Special Issue points the way to a new kind of discussion, one which begins from the complex realities of the borderland drug economies, embedded in systems of social, national and global inequality, where state formation processes reproduce violence, and where borderlanders are forced to act in conditions they do not choose. These can contribute to new violent and illegal orders or potentially to new approaches to regulating an ever adaptive production and trafficking process and consumer market. Engaging and enabling social agency in borderland areas to build violence reducing and legally regulated income generating livelihoods, requires a shift in mindset. This inductively brings the borderlanders in search of sustainable livelihoods into drugs policy debates, as a new starting point for rebuilding a road that might lead from drugs to peace and without a framework of war behind it.

\section{REFERENCES}


Ballvé, T. (2020) The Frontier Effect. State Formation and Violence in Colombia. Ithaca: Cornell University Press.

Idler, A. (2019) Borderland Battles: Violence, Crime and Governance at the Edges of Colombia's War. Oxford: Oxford University Press.

Insight Crime (26 June 2020) Drop in Coca Crops, Increase in Colombian Cocaine. Retrieved 29 September 2020 from:

https://www.insightcrime.org/news/brief/drop-coca-increase-colombia-cocaine/

LeGrand, C. (1986) Frontier Expansion and Peasant Protest in Colombia 1830-1936. Albuquerque:University of New Mexico Press.

Misión para la Transformación del Campo (2015) El Campo Colombiano: Un Camino hacia el Bienestar y la Paz. Bogota:DNP.

Molano, A. (1989) Colonos, Estado y Violencia. Revista Foro, no. 9. Bogota.

Moestue, H., Moestue L., and Muggah, R. (2013) Youth Violence Prevention in Latin America and the Caribbean: A Scoping Review of the Evidence. NOREF Report, August 2013. Oslo: Norwegian Peacebuilding Resource Centre.

Pearce, J. (1990) Colombia: Inside the Labyrinth. London: Latin America Bureau 
Pearce, J. (2010) Perverse State Formation and Securitized Democracy in Latin America. Democratization, 17(2), pp. 286-306.

Pearce, J. and Perea, C. M. (2019) Post-war and Non-war Violences: Learning about Peace and Peacebuiliding from Latin America. Peacebuilding Vol.7, 3. pp. 247-253.

Pearce, J. (2020) Politics without Violence? Towards a Post Weberian Enlightenment. London: Palgrave Macmillan.

Thoumi, F. ( 2019) The Relationship between Illegal Drugs and Violence: Is There a Cause and Effect? Retrieved 29 September 2020 from: https://franciscothoumi.com/2019/05/06/the-relationship-between-illegal-drugs-and-violence-is-there-acause-and-effect/

UNODC (2020a.) Booklet 1. Executive Summary. Impact of COVID 19 Policy Implications. World Drugs Report 2020. Vienna: UNODC. Retrieved 29 September 2020 from: https://wdr.unodc.org/wdr2020/field/WDR20 BOOKLET 1.pdf

UNODC (2020b) Booklet 5. Socioeconomic characteristics and drug use disorders.2020 World Drug Report. Vienna: UNODC. Retrieved 29 September 2020 from: https://wdr.unodc.org/wdr2020/field/WDR20 Booklet 5.pdf UNODC (2020c) Booklet 3. Drug Supply. 2020 World Drug Report. Retrieved 29 September 2020 from: https://wdr.unodc.org/wdr2020/field/WDR20 Booklet 3.pdf 